\title{
Nannobacteria and the formation of framboidal pyrite: Textural evidence
}

\author{
ROBERT L FOLK \\ Department of Geosciences, University of Texas, Austin, Texas, USA.
}

\begin{abstract}
Study of sedimentary pyrite in the form of framboids, euhedral crystals or metasomatic masses has revealed that their surfaces are commonly covered with spheroids of about $50 \mathrm{~nm}$. This applies to all the examples studied, from modern to Proterozoic. These spheroids are interpreted as the pyritized corpses of nannobacterial cells; if correct, this indicates that precipitation of iron sulfide was performed by these dwarf forms of bacteria, often associated with decaying organic matter.
\end{abstract}

\section{Introduction}

Pyrite 'framboids' (Rust 1935) are minute raspberry-shaped spherical aggregates, $2-50 \mu \mathrm{m}$ in diameter, composed of assemblages of tiny crystallites of $0.5-2 \mu \mathrm{m}$, often in geometrical arrays. The crystallites themselves are euhedral cubes, octahedra or pyritohedra and they are embedded in organic slime (Bates and Strahl 1957; Love and Amstutz 1966). Framboidal pyrite is very common in reducing sediments such as modern dark muds, or in ancient dark shales and limestones, and even among the anoxic pages of old books with ink containing sulfate (Garcia-Guinea et al 1997). For half a century it has been recognized that they have a very close association with decaying flesh or organic matter and form very early; and an organic, or more specifically, bacterial origin passing through various ironsulfur compounds has been commonly proposed (Schneiderhöhn 1923; Love 1957, 1962, 1967; Love and Murray 1963; Raiswell 1982; Love et al 1984; Suits and Wilkin 1998). There has ensued much discussion on the direct bacterial vs. organic vs. inorganic origin, e.g., Schouten 1946; Vallentyne 1962, 1963; Schopf 1965; Love and Amstutz 1966; Rickard 1970; Sweeney and Kaplan 1973; Wilkin and Barnes 1997; Kohn et al 1998; Konhauser 1998; Folk 1998; Schieber and Baird 2001; Schieber 2002a. Donald and Southam (1999) report FeS precipitating upon bacterial cell walls and Posfai et al (1998) show it forming within cells of normal sized bacteria.

Despite this work there has been very little direct evidence in the form of a 'body-count' of actual bacterial corpses preserved within the pyrite. Schopf (1965) used polished sections and found 'normal-size' bacterial rods about 1 micron long, and Schieber (2002a, b) described $0.5-2 \mu \mathrm{m}$ ovoids in etched pyrite concretions. No previous workers have thought to look for nannobacteria (dwarf forms about 0.1 micron, Folk 1993) because the idea had not yet arisen, thus there is very little SEM work carried out on pyrite with the high magnifications required, i.e., 20,000-75, 000×. A few workers, however, have inadvertently come across tiny round bodies in the $0.05-0.2$ micron range, which I consider to be probable nannobacteria (Clark and Lutz 1980; Postma 1982; Sassano and Schrijver 1989; Sawlowicz 1993; Bang 1994; Ariztegui and Dobson 1996).

An obvious association with bacteria is the fact that framboidal pyrite is often found within the body chambers of small fossils such as foraminifera, ostracods, and radiolaria, where flesh had rotted (Love and Murray 1963). A remarkable example of early formation is the occurrence described by Clark and Lutz (1980) who showed 0.1 micron pyrite spheroids growing within a living mollusk shell.

Keywords. Nannobacteria; pyrite; framboid. 


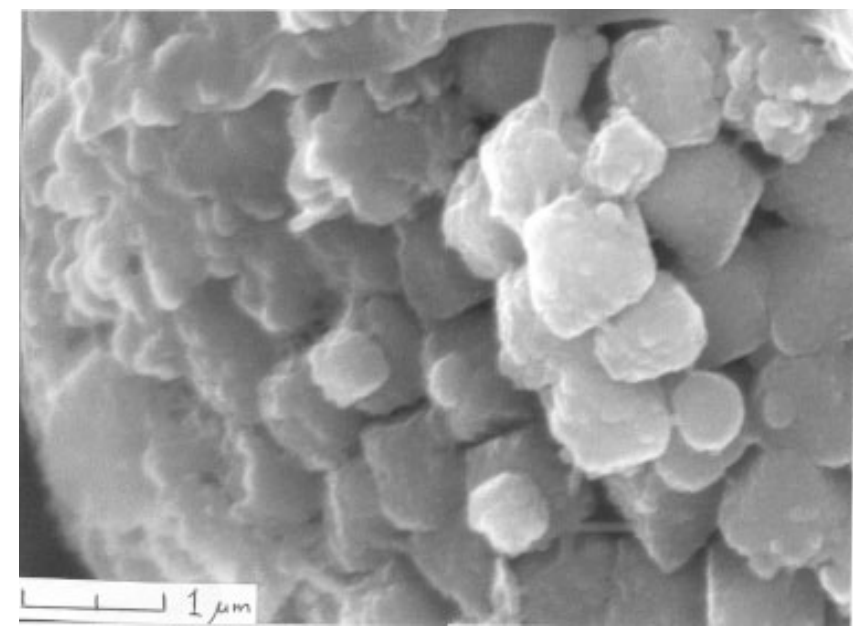

Figure 1. Black sulfur-microbial mat from Kane Cave, Wyoming, coll. A S Engel. Edge of a framboid with crystallites showing 60-80 $\mathrm{nm}$ nannobacteria.

\section{Results}

The specimen is gold-coated for 30 seconds only as longer times can induce nannobacteria-like artifacts (Folk and Lynch 1997b). In the search for such minute textures, using magnifications of up to $100,000 \times$, our JEOL JSM. T330A must be adjusted carefully for maximum performance. We used a very close working distance $(9 \mathrm{~mm})$, highest voltage $(30 \mathrm{kv})$, and a large and dim spot size $(9$ to 11 on our dial). Careful stigmation is of course essential, and a positive attitude and knowing just what to look for are vital. We can then identify presence/absence of objects as small as $10-15 \mathrm{~nm}$, and distinguish spheroidal vs. simple crystal shapes (such as cubes or octahedra) at around $25 \mathrm{~nm}$.

I will discuss examples of sedimentary pyrite from youngest to oldest, giving examples of the relationship between nannobacteria and that mineral. From the modern back to the Proterozoic, all examples appear to be very similar.

Annette Summers Engel (Ph.D. in progress, University of Texas) is examining sulfur microbial mats from Kane Cave, Bighorn Co., Wyoming. Black mats (color N1) contain 5-20 micron framboids, with individual crystallites of 0.5 micron that vary from octahedra to pyritohedra, with roundish shapes. These are covered with spheroidal nannoforms of 25-85 nm (figure 1), and a few filaments $10-15 \mathrm{~nm}$ wide, as well as some larger mucus strands or collapsed sulfur bacteria. This anaerobic microbial mat occurs in a completely dark cave; water is $\mathrm{H}_{2} \mathrm{~S}$-rich, $\mathrm{pH} \sim 7.2, \mathrm{~T}=218^{\circ} \mathrm{C}$. Sulfatereducing bacteria as filaments, coccoids and bacilli are present, $<10^{3}$ cells per $\mathrm{mL}$.

Dark mud from the Recent Gulf of Mexico, offshore Texas, contains pyrite framboids with 0.5-1 micron crystallites, ranging from cubes to

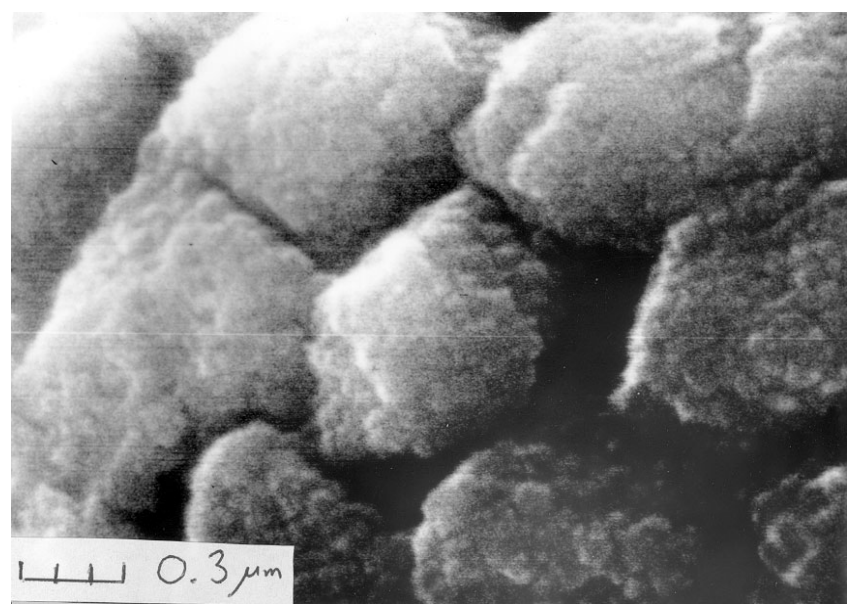

Figure 2. Modern mud, Gulf of Mexico, coll. F L Lynch. Pyrite crystallites with $40 \mathrm{~nm}$ nannobacteria.

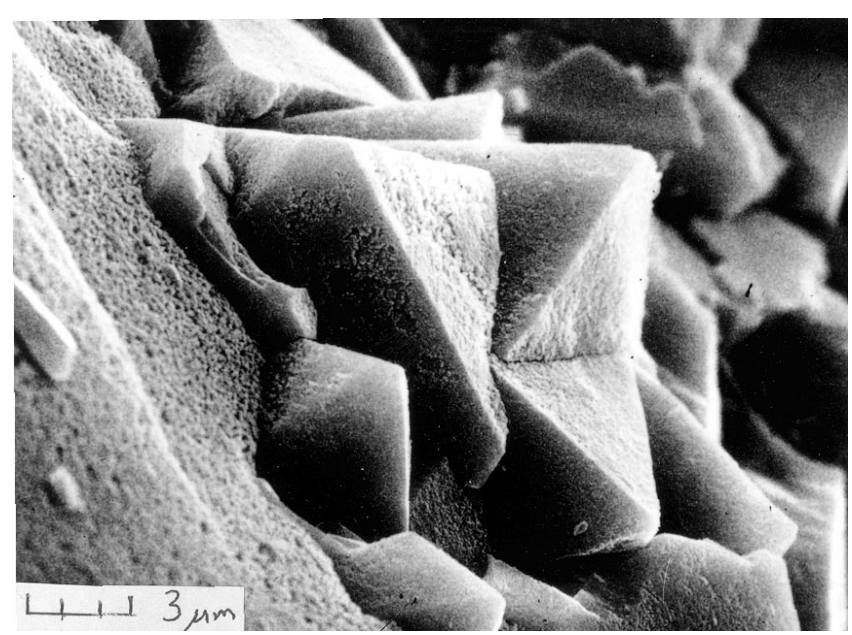

Figure 3. Euhedral pyrite octahedra in opal, Miocene, LA; coll. D Trombatore.

pyritohedra to octahedra. All are covered with $40 \mathrm{~nm}$ nannobacteria (figure 2).

A small bed of precious opal cementing sandstone of Miocene age (Fleming Fm.) occurs in Leesville, Vernon Parish, LA (Dennis Trombatore, coll. - see Stevens 1999 and Thomas 1986). This consists of a mass of $50-100 \mathrm{~nm}$ opal spheres, arranged in regular geometrical array, and within the opal are clumps of brilliant pyrite crystals. The pyrite here forms masses of 2-10 micron euhedral crystals, almost all as octahedra (figure 3 ). The crystals are entirely made up of nannobacterial cells, $30-50 \mathrm{~nm}$. In the centers of octahedral faces, the nannobacteria occur as thinly scattered individuals, then become denser but still discrete, like a layer of peas on a table (figure 4); but toward the edges of faces, nannobacterial cells merge into sheets so that their separate identity becomes blurred by precipitation of an inter-ball cement, probably also pyrite (figure 5). 


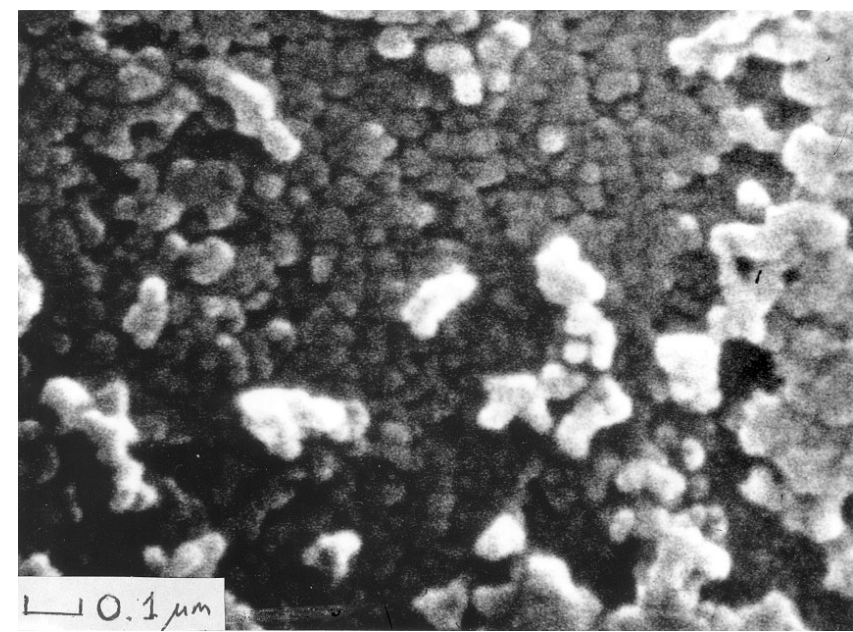

Figure 4. Close-up of the central portion of an octahedral face, from a crystal in figure 3. A few spheroidal nannobacterial cells of $30-50 \mathrm{~nm}$ lie scattered on the surface but coalesce to the right. The underlying layer is entirely composed of nannobacteria making a continuous expanse.

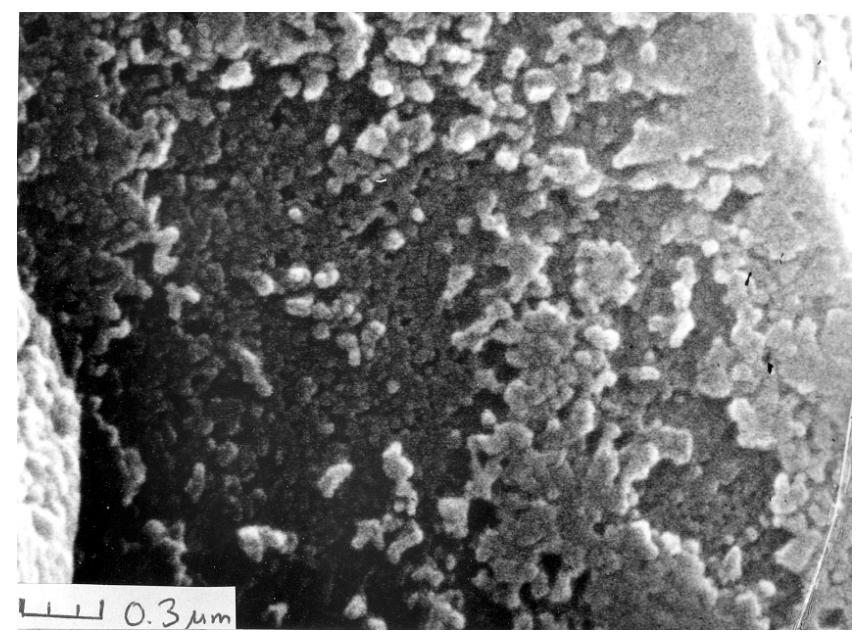

Figure 5. Edge of an octahedron from figure 3. Nannobacterial cells form scattered individuals toward the center of the face (centered in photo), but coalesce into sheets of balls to the right as the octahedral edge is approached.

Hudgeons (1999) has described septarian concretions from the Eocene Marquez Shale, Bastrop Co., Texas. Within the concretions are masses of pyrite $10-20 \mu \mathrm{m}$ in diameter, consisting of crystallites as 0.5-2 micron octahedra; these have surfaces covered with $30-80 \mathrm{~nm}$ nannobacteria.

The cretaceous Austin chalk (fresh excavation for new wing to Geology building, University of Teas, coll. W Woods) is light gray, and etching reveals common framboids $10-20 \mu \mathrm{m}$ in diameter (figure 6). Crystallites (octahedra beveled by cube faces) range from $0.5-1 \mu \mathrm{m}$, and most are coated with closely packed $25-40 \mathrm{~nm}$ nannobacterial cells (figures 7 and 8). There are areas covered with mucus sheets, and a few distinct streptococcus-like

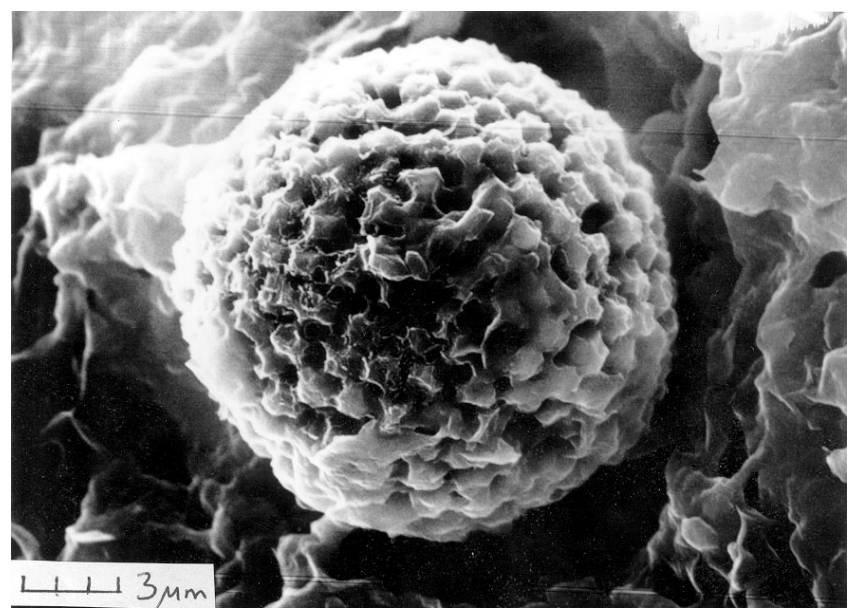

Figure 6. Pyrite framboid, Cretaceous Austin Chalk, Texas, coll. B Woods.

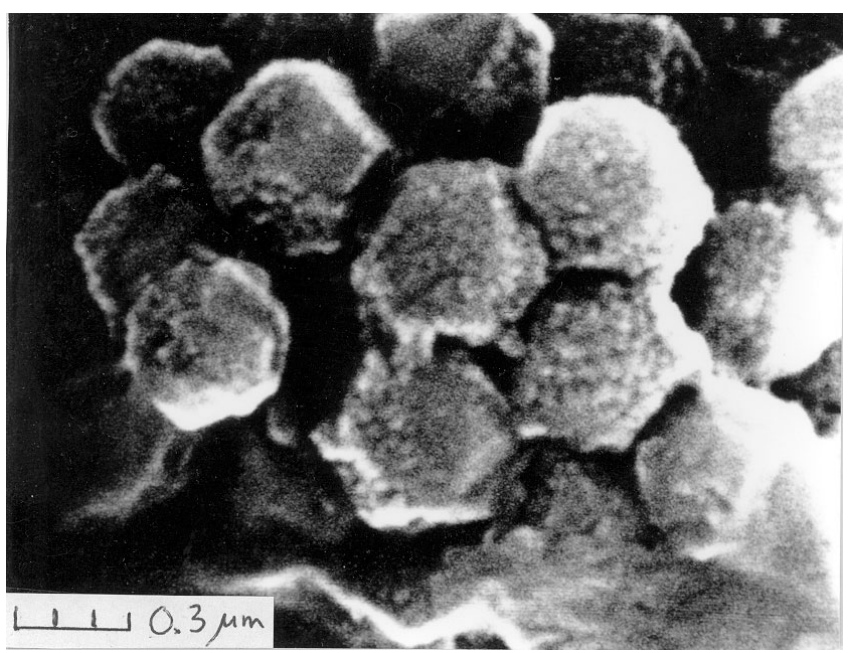

Figure 7. Pyrite crystallites with nannobacterial cells, from figure 6 .

chains of $25-40 \mathrm{~nm}$ balls (figure 9). In contrast to the nannobacteria-rich textures of most pyrite, some crystals show clean, euhedral facets with no nannotexture (also figure 9). These may be inorganic, but with the precipitation triggered by micro-organisms - e.g., inorganic 'overgrowths' on a nannobacterial nucleus, similar to the process envisioned on a larger scale by Raiswell (1982).

The Devonian Woodford black shale (West Texas, coll. S P Ellison) contains 10-50 micron framboids, consisting of crystallites ranging from 0.5-5 microns; these vary from pyritohedra to rounded shapes and are enmeshed with some organic filaments. The nannobacteria form $30-40 \mathrm{~nm}$ balls laid in overlapping, shingling sheets.

Ordovician Decorah shale of St Paul, Ramsey, Co., Minnesota (coll. C Schneider) contains layers of limonite oolites and fossils (figure 10). Ooid 


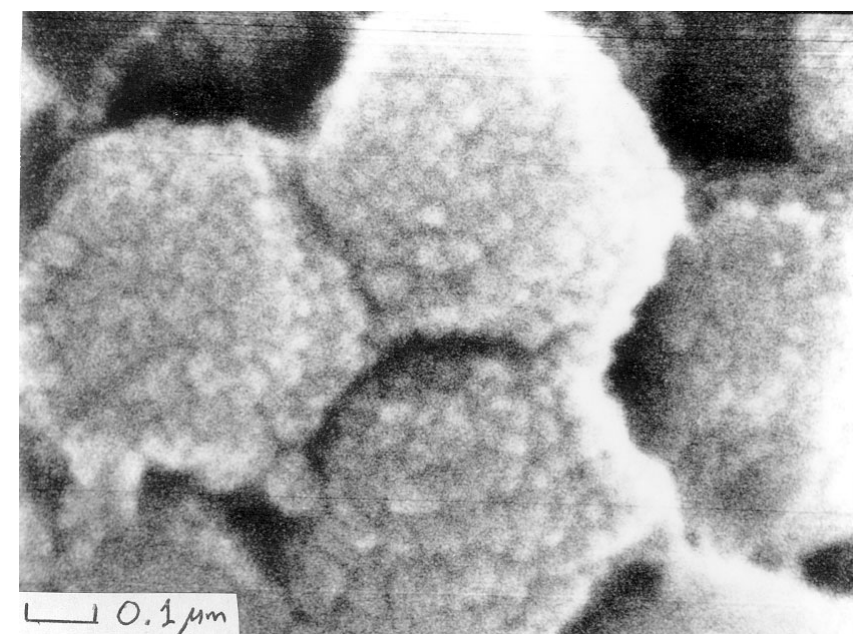

Figure 8. Close-up of figure 7. Euhedral crystallites made of $20-40 \mathrm{~nm}$ balls.

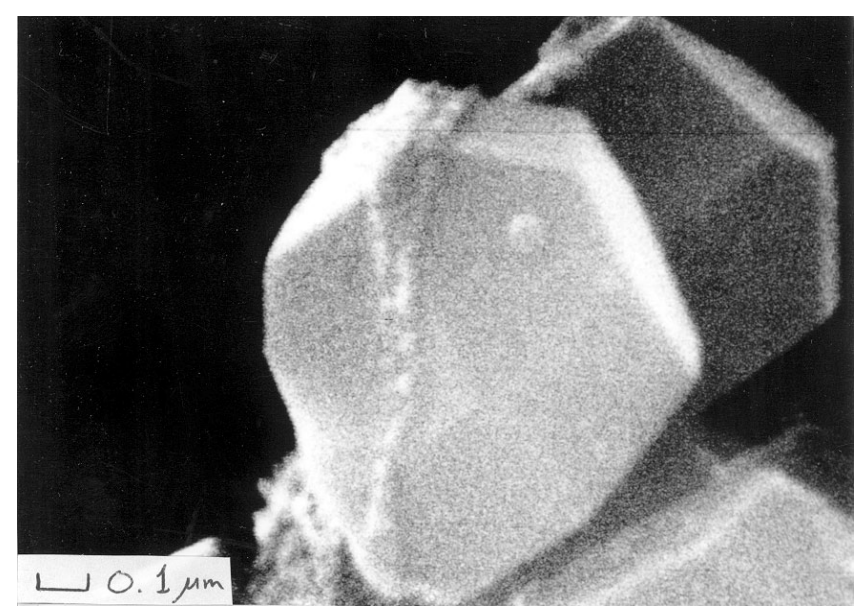

Figure 9. From the specimen of figure 7. Rare pyrite crystallite that is euhedral with smooth faces; but there are two nannobacterial filaments (like Streptococcus) draped over the crystal, plus a lone nannobacterial cell. The euhedral nature implies that this pyrite may be inorganicallyprecipitated. The chain of balls proves the 'life' status of nannobacteria.

layers (figure 11) consist of $30-45 \mathrm{~nm}$ nannobacterial cells (figure 12), in some layers quite distinct, in other layers merged to form only vaguely balltextured sheets; in this way they resemble the octahedra from Louisiana opal.

A sample from Proterozoic black shale contained abundant $2-5 \mu \mathrm{m}$ framboids, with multifaceted crystallites of about $0.3 \mu \mathrm{m}$. Abundant nannobacterial cells averaged $40-50 \mathrm{~nm}$. One framboid is most remarkable in that the organic portion, with the usual texture of nannospheres, has scattered $0.5 \mu \mathrm{m}$ overgrowths of inorganically-precipitated pyrite that show planar, geometric faces. Unfortunately no publishable photos are available for this ancient example.

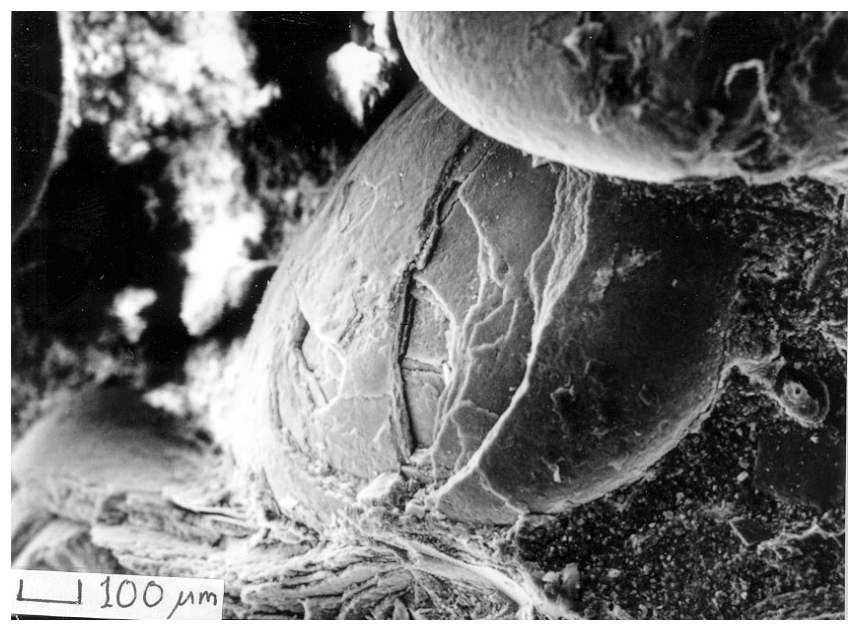

Figure 10. Ordovician of Minnesota (C Schneider coll.), with a limonite ooid, probably pseudomorphous after pyrite.

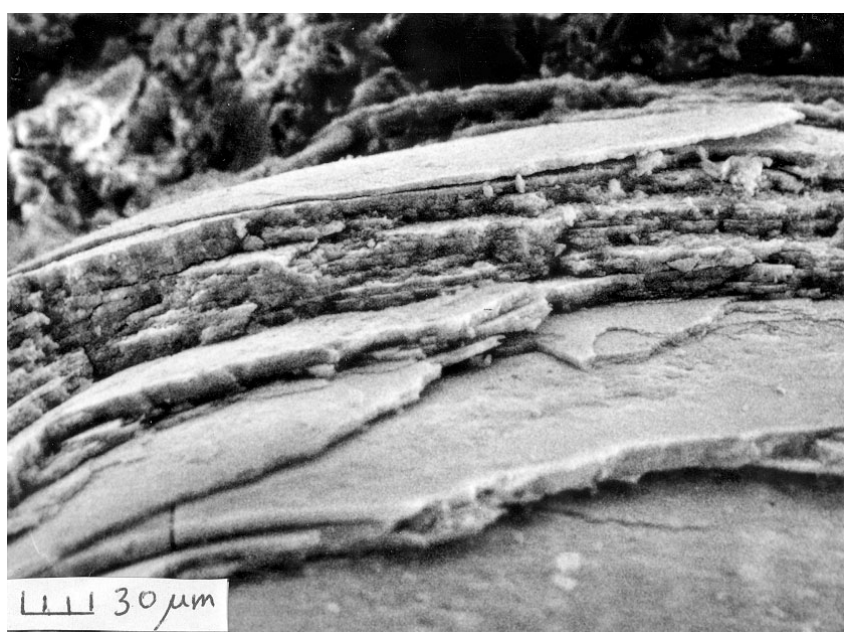

Figure 11. Close-up of the above showing concentric ooid shells.

\section{Discussion}

Of interest is the fact that, though the framboids vary greatly in size, and their contained crystallites also show a rather wide variation in size (typically $0.5-2 \mu \mathrm{m}$ ) the great majority of nannobacterial cells lie between 30 and $50 \mathrm{~nm}$. This is approximately the same size as the nannobacteria in limestones (Folk and Chafetz 2000); shales (Folk and Lynch 1997b); on Mars (Folk and Lynch 1997a; Folk and Taylor 2002) and in human arterial plaque made of hydroxyapatite (Folk et al 2001). Thus the cells are the same size in sulfides, carbonates, silicates, and phosphates and in the extra-terrestrial realm, and similar size nannobacteria have been cultured by many laboratories (Folk and Taylor 2002).

The fact that in many minerals (including pyrite) the crystals are constructed of shingling 


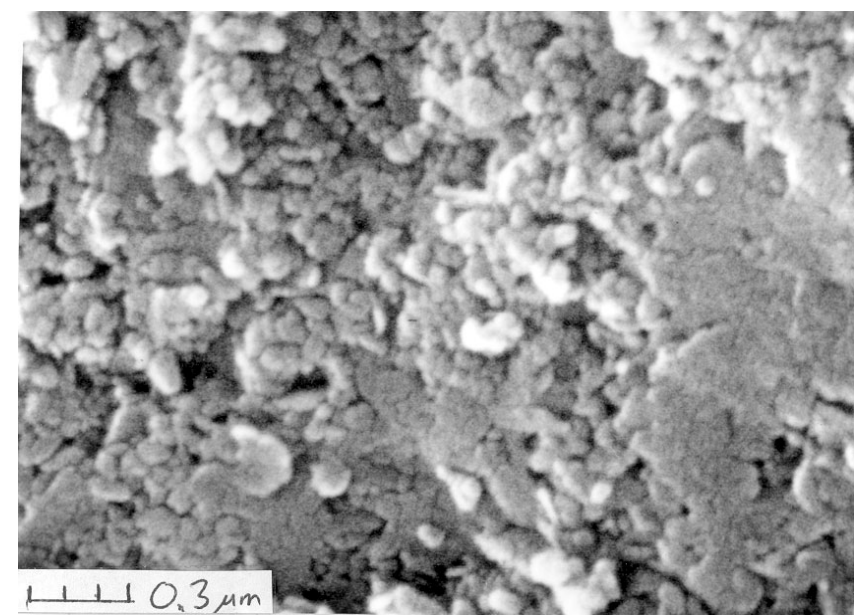

Figure 12. As above, but looking down on the surface of the ooid shell. It is made of $25-45 \mathrm{~nm}$ nannobacterial cells, distinct in the center but merging into a sheet at right. Whether this texture is indicative of the original pyrite, or the diagenetic limonite, is not known.

sheets of nannobacterial balls, indicates that the little cells are actually producing the mineral rather than simply lying upon the surface.

Though morphologically it appears that precipitation by nannobacteria is responsible for the formation of the pyrite, many things are still unclear. This does not answer why the framboids are generally so close to being perfect equidimensional spheres (a spherical redox gradient, perhaps?) or why the crystallites arrange themselves in such perfect geometrical arrays or even sometimes, different crystals with parallel crystal facets extending over a large area (e.g., Love and Amstutz 1966; Love 1967). They must arrange themselves by 'communicating' with electrical fields extending over distances of a few microns. And how do the individual nannobacteria cells interact with each other so that they produce a geometrically isotropic, well-faceted crystallite?

\section{Conclusion}

Many examples of sedimentary pyrite, ranging in age from Proterozoic to Recent, and in morphology from framboids to euhedral crystals, are made up of $30-50 \mathrm{~nm}$ spheroids. These are interpreted as fossils of the nannobacterial cells that precipitated the iron sulfide(s).

Note added in proof: Further research on the black therapeutic muds of Viterbo, Italy, has shown framboids made of 1-2 micron crystallites that range from spheres through watermelon shapes to euhedra, giving rise to the suggestion that the crystallites represent pyritized 'big' bacterial bodies only slightly enlarged by further pyrite growth; the nannobacteria are then symbiotic or parasitic on their larger fellows.

\section{Acknowledgements}

It is a pleasure to acknowledge the communication processing skills of Annamaria Christian and Peggy Hairston, and the photographic expertise of Joe Jaworski.

\section{References}

Ariztegui D and Dobson J 1996 Magnetic Investigation of Framboidal Greigite Formation, Lake St. Moritz, Switzerland; The Holocene 6 235-241.

Bang B S 1994 Framboidal Pyrite and Associated Organic Matrices; In: Surface Treatment: Cleaning, stabilization and coatings, Kejser U B (ed.) Geol. Museum, Univ. Copenhagen, Contr. to Geol., \#735, 65-82.

Bates T F and Strahl E O 1957 Mineralogy, Petrography and Radioactivity of Representative Samples of Chattanooga Shale; Bull. Geol. Soc. America 68 1305-1314.

Clark G R II and Lutz R A 1980 Pyritization in the Shells of Living Bivalves; Geol. 8 268-271.

Donald R and Southam G 1999 Low Temperature Anaerobic Bacterial Diagenesis of Ferrous Monosulfide to Pyrite; Geoch. Cosm. Acta. 63 2019-2023.

Folk R L 1993 SEM Imaging of Bacteria and Nannobacteria in Carbonate Sediments and Rocks; J. Sed. Petrol. 63 990-999.

Folk R L 1998 Nannobacteria and the Precipitation of Pyrite as Framboids and Larger Crystals: Some Comparisons with Copper Minerals (abs.) SE section; Geol. Soc. Amer. (Charleston, WV) 3012.

Folk R L and Chafetz H S 2000 Bacterially Induced Microscale and Nanoscale Carbonate Precipitates; In: Microbial Sediments, Robert E Riding and Stanley M Awramik (eds) (Berlin: Springer Verlag) Pp. 40-49.

Folk R L, Kirkland B L, Rodgers J C, Rodgers G P, Rasmussen T E, Lieske C, Charlesworth J E, Severson S R and Miller V M 2001 Precipitation of minerals in human arterial plaque: the potential role of nannobacteria (abs); Geol. Soc. America Ann. Mtg. Boston 33(6) 189.

Folk R L and Lynch F L 1997a Nannobacteria are Alive on Earth as well as Mars; Proc. SPIE 3111 406-419.

Folk R L and Lynch F L 1997b The Possible Role of Nannobacteria (dwarf bacteria) in Clay Mineral Diagenesis and the Importance of Careful Sample Preparation in High Magnification SEM study; J. Sed. Res. 67 $583-589$.

Folk R L and Taylor L A 2002 Nannobacterial Alteration of Pyroxenes in Martian Meteorite ALH84001; Meteoritics \& Planetary Sci. 37 1057-1070.

Garcia-Guinea J, Martinez-Frias J, Gonzales-Martin R and Zamora L 1997 Framboidal Pyrites in Antique Books; Nature 388631.

Hudgeons G L 1999 Petrology and Geochemistry of the Marquez Shale Septarian Concretions, Bastrop Co., TX. Unpubl. MS. Thesis, Univ. of Texas, p. 108.

Kohn M L, Riciperti L, Stakes D and Orange D 1998 Sulfur Isotope Variability in Biogenic Pyrite: Reflections of Heterogeneous Bacterial Colonizations; Amer. Mineralogist 83 1454-1468. 
Konhauser K O 1998 Diversity of Bacterial Iron Mineralization; Earth Sci. Rev. 43 91-121.

Love L G 1957 Micro-Organisms and the Presence of Syngenetic Pyrite; Quart. J. Geol. Soc. London 113 429-440.

Love L G 1962 Biogenic Primary Sulfide of the Permian Kupfenschiefer and Marl Slate; Econ. Geol. 57 350-366.

Love L G 1967 Early Diagenetic Iron Sulfide in Recent Sediments of the Wash (England); Sedimentology 9 327-352.

Love L G, Al-Kaisy, Adil T H and Brockley Harry 1984 Mineral and Organic Material in Matrices and Coatings of Framboidal Pyrite from Pennsylvanian Sediments, England; J. Sed. Petr. 54 869-876.

Love L G and Amstutz G C 1966 Review of Microscopic Pyrite from the Devonian Chattanooga Shale and Rammelsberg Banderz; Fortschr. Mineral 43 273-309.

Love L G and Murray J W 1963 Biogenic Pyrite in Recent Sediments of Christchurch Harbour, England; Amer. J. Sci. 261 433-448.

Posfai M, Buseck P R, Bazylinski D A and Frankel R B 1998 Reaction Sequence of Iron Sulfide Minerals in Bacteria and Their Use as Biomarkers; Science 280 880-883.

Postma D 1982 Pyrite and Siderite Formation in Brackish and Fresh Water Swamp Sediments; Amer. J. Sci. 282 1151-1183.

Raiswell R 1982 Pyrite Texture, Isotropic Composition and the Availability of Iron; Amer. J. Sci. 282 1244-1263.

Rickard D T 1970 The Origin of Framboids; Lithos 3 267-293.

Rust G W 1935 Colloidal Primary Copper Ores at Cornwall Mines, Southeastern Missouri; J. Geol. 43 398-426.

Sassano G P and Schrijver K 1989 Framboidal Pyrite: Early Diagenetic, Late Diagenetic and Hydrothermal Occurrences, Cambrian-Ordovician, Quebec; Amer. J. Sci. 289 $167-179$.
Sawlowicz Z 1993 Pyrite Framboids and Their Development; Geol. Rundschau 82 148-156.

Schieber J 2002a Sedimentary Pyrite: a Window into the Microbial Past; Geology 30 531-534.

Schieber J 2002b The Role of Organic Slime Matrix in the Formation of Pyritized Burrow Trails and Pyrite Concretions; Palaios 17 104-109.

Schieber J and Baird G 2001 On the Origin and Significance of Pyrite Spheres in Devonian Black Shales of North America; J. Sed. Res. 71 155-166.

Schneiderhöhn H 1923 Chalkographische Untersuchung des Mansfelder Kupferschiefers. N. Jb. Fur Miner. Geol. und Palaont. Beilage-Band 47 1-38.

Schopf J M 1965 Fossil Iron Bacteria Preserved in Pyrite; Proc. Amer. Philos. Soc. 109 288-308.

Schouten C 1946 The Role of Sulphur Bacteria in the Formation of the So-called Sedimentary Copper Ores and Pyritic Ore Bodies; Econ. Geol. 41 517-538.

Stevens B F 1999 Louisiana Opal. Natalby, LA, Exquisite Stone and Creations.

Suits N S and Wilkin R J 1998 Pyrite Formation in the Water Column and Sediments of a Meromictic Lake; Geol. 26 1099-1102.

Sweeney R E and Kaplan I R 1973 Pyrite Framboid Formation; Laboratory Synthesis and Marine Sediments; Econ. Geol. 68 618-634.

Thomas L H 1986 Elusive in Louisiana; Lapidary J. 40(3) 54.

Vallentyne J R 1962 Concerning Love, Microfossils and Pyrite Spherules; Trans. N.Y. Acad. Sci. Ser. 2, 25 177-189.

Vallentyne J R 1963 Isolation of Pyrite Spherules from Recent Sediments; Limnol. \& Oceanogr. 8 16-30.

Wilkin R T and Barnes H L 1997 Formation Processes of Framboidal Pyrite; Geoch. et Cosm. Acta. 61 $323-339$ 